American Journal of Marine Research and Reviews

(ISSN:2578-2126)

\title{
Survey of the Seaweeds of the Beach of Pina, Recife Pernambuco
}

\author{
SILVA, E. V', ANJOS, F. B. R. ${ }^{1}$, CARVALHO, R. C. $X^{2}$. \\ ${ }^{1}$ UNIVERSIDADE FEDERAL DE PERNAMBUCO, RECIFE - PE. \\ ${ }^{2}$ UNIVERSIDADE DE PERNAMBUCO, RECIFE - PE.
}

\section{ABSTRACT}

The constant interference of human activities has had direct and indirect impacts on aquatic environments with consequences for water quality for aquatic biota and the functioning of ecosystems, thereby reducing the ability to use. This study aimed to describe the qualitative and quantitative variation of species of macroalgae from Praia do Pina, Recife-PE, in the rainy season and drought. The collections were made in August 2007 (rainy season) and January 2008 (period of drought). Data on the occurrence of macroalgae were collected by snorkeling using the combined techniques of sampling belt transects $(50 \mathrm{~m} \times 1 \mathrm{~m})$ and quadrats $(1 \mathrm{~m} \times 1 \mathrm{~m})$. The species of greatest abundance in both periods were almost the same: Ulva lactuca, U. fasciata, U. intestinalis, Caulerpa sertularioides, C. filiformis; C.prolifera; C.racemosa, and $\mathrm{C}$. lentillifera; being found in smaller quantities: Pterocladia capillaceous, Hypnea musciformis, $\mathrm{H}$. pannosa, $\mathrm{H}$. cervicornis, Sargassum Muticum, S. vulgare, S. ilicifolium, Padin Pavoni, P. tetrastromatica, Dictyota dichotoma, Gracilaria warts and G. Salicornia. The two species were only found in Glacilaria period of drought and the species $\mathrm{S}$. ilicifolium was found during the rainy season. About $80 \%$ of macroalgal distribution in reef studied is composed of individuals belonging to the phylum Chlorophyta, $12 \%$ are representatives of the phylum Phaeophyta and $8 \%$ are belonging to the phylum Rodhophyta. These percentages are very close to the values presented in two urban beaches in the Metropolitan Region of Recife and a beach on the northern coast of the state of Pernambuco, where areas have been intensified the processes of human occupation and exploitation, and increasing industrialization. The predominance of species of Chlorophyta may represent a greater tolerance to the flora of the pollutants.
*Correspondence to Author:

SILVA, E. V

UNIVERSIDADE FEDERAL DE PERNAMBUCO, RECIFE - PE.

How to cite this article:

SILVA, E. V, ANJOS, F. B. R., CARVALHO, R. C. X.Survey of the Seaweeds of the Beach of Pina, Recife Pernambuco. American Journal of Marine Research and Reviews, 2019; $2: 9$

\section{2 eScî̀Pub}

eSciPub LLC, Houston, TX USA. Website: http://escipub.com/

Keywords: Praia do Pina, macroalgae, seasonality, pollution. 


\section{INTRODUCTION}

The coast of the Metropolitan Region of Recife is one of the regional centers of the tourist area of the region of Northeast Brazil, for their climatological characteristics, by having a beautiful historical and numerous resorts. The state plays the role of center of tourist attraction, and center core receiver transmitter and distributor in the national tourism (DUARTE, 1993).

The beach of Pina is located in the South Atlantic ocean and the action suffers from Brazil Current, a branch of South Equatorial Current South. Near the beach line of the current longitudinal work yet, the return currents, currents generated by waves and the tides. The longitudinal ones are most important, moving parallel to the coastline, with a speed that varies according to the angle of incidence of waves. The currents generated by waves are related to the movement ante beach - coast outside, varying with the location and climate of wave (ROLLNIC,2002).

The tides that act in Pernambuco are the type mesomaré, dominated by waves, and under action of constant trade winds. This represents a major influence on the estuarine environments and of beachs (MARTINS, 1997). The tides of the coast of Pernambuco is semidiurna type, with average time of 12:42 hours, presenting two flood and two low tides per lunar day, the values representing the height of the tide are from 2.4 $\mathrm{m}$ to maximum sizígia and 2, 1 to square up (COUTINHO et al., 1997).

Along the coastline of metropolitan Recife, the beaches are composed of quartz sand, which touches on some places the lines of reefs. In a small distance from the coast may occur other lines of reef that touches only during low tide (OLIVEIRA FILHO, 2001). The area under study presents a complex hydrodynamics due to the presence of several lines of reefs of sandstone and morphology of beachs close to the surf zone of approximately $50 \mathrm{~m}$.
There are a large number of organisms found in the reefs. The major groups of macrofauna found in the reef are Pina Cnidaria (Palythoa sp., Physalia physalia, Zoanthus sp.), Mollusca (Aphlysia dactylomela, Brachidontes sp., Bulia sp., Cerithium atratum, Littorina scabra anguilfera), Crustacea (Chthamalus proteus, Eriphia gonagra, Ligia exotica), Echinodermata (Echinometra lucunter, Ophion reticulata). Among these, E. lucunter dominate (Echinodermata) and Brachidontes (Mollusca) (NUNES et al, 2005).

Among the most significant reef organisms are distinguished from macroalgal communities, on their species richness, cover and abundance (MANSILLA and PEREIRA, 2001). They play other important ecological functions as a place of habitat, shelter and reproduction.

In oceans and seas of the macroalgal serve food and shelter for many species of organisms, comprising the first link in the food chain essential for the maintenance of marine life. Besides their environmental importance, and social roles are related to human survival and maintenance of biological equilibrium, ensuring the continuity of life on the planet (VIDOTI and ROLLEMBERG, 2004, SANTOS et al, 2006).

The level of knowledge about the vegetation tidal region between the northeastern coast is growing every day (PEREIRA, 2007). According to Nunes (2004), the reef area, the more common genera or dominant algal flora are: Ulva spp., Enteromorpha spp., Halimeda spp., Hypnea spp., Gracilaria spp., Sargassum spp. Among many others.

Oliveira et al., (2002) reports that the catalog of existing marine macroalgae should have their number increased around $20 \%$ to $30 \%$, approximately 800 to 900 species, excluding the cyanobacteria. From a total of 643 infrageneric rate of macroalgae are classified 388 Rhodophyta, 88 Phaeophyta and 167 Clhorophyta.

In view of the importance of knowing the biodiversity of coastal Pernambuco macroalgae 
was developed in a survey evaluating the $08 \cong 04$ '03"and $08 \cong 05$ ' 06 "Lat. $S$ and the change as much qualitative as quantitative meridians $34^{\circ}-52^{\prime} 16^{\prime \prime}$ and $34^{\circ} 53^{\prime} 58^{\prime \prime L} L$ ng W species of macroalgae from the Praia do Pina, (CASTRO, 2003).

Recife-PE, depending on sazanolidade.

\section{METHODOLOGY}

It is a beach located in the urban area full of Recife, which receives the influence estuarine basin of Pina. It is situated between the parallels
The collection station is located opposite the Recife Praia Hotel, in the coordinates $8^{\circ} 04^{\prime} 48$ "S and $34^{\circ} 52$ '35" W (Figure 1 and 2 ). This area was chosen due to proximity to the sewage that flow over the reefs.

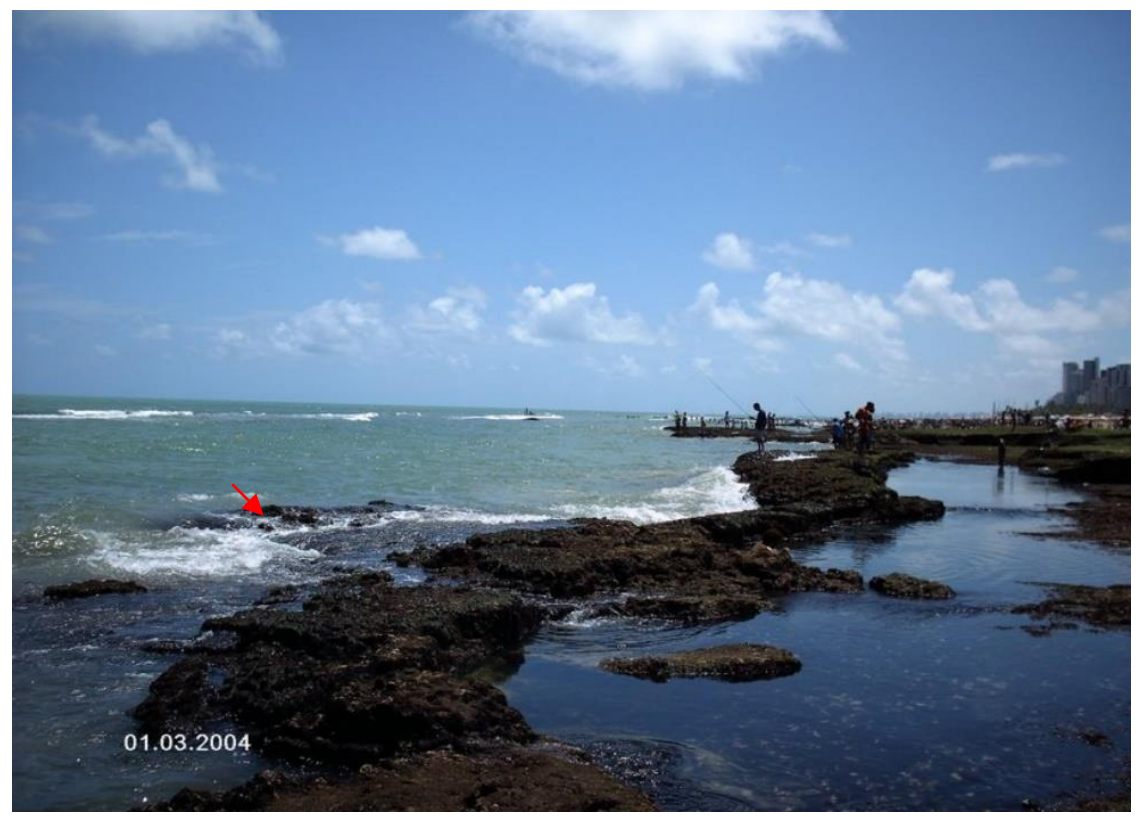

Figure 1 - Overview of the sandstone reef on the beach of Pina in detail the location of collection.

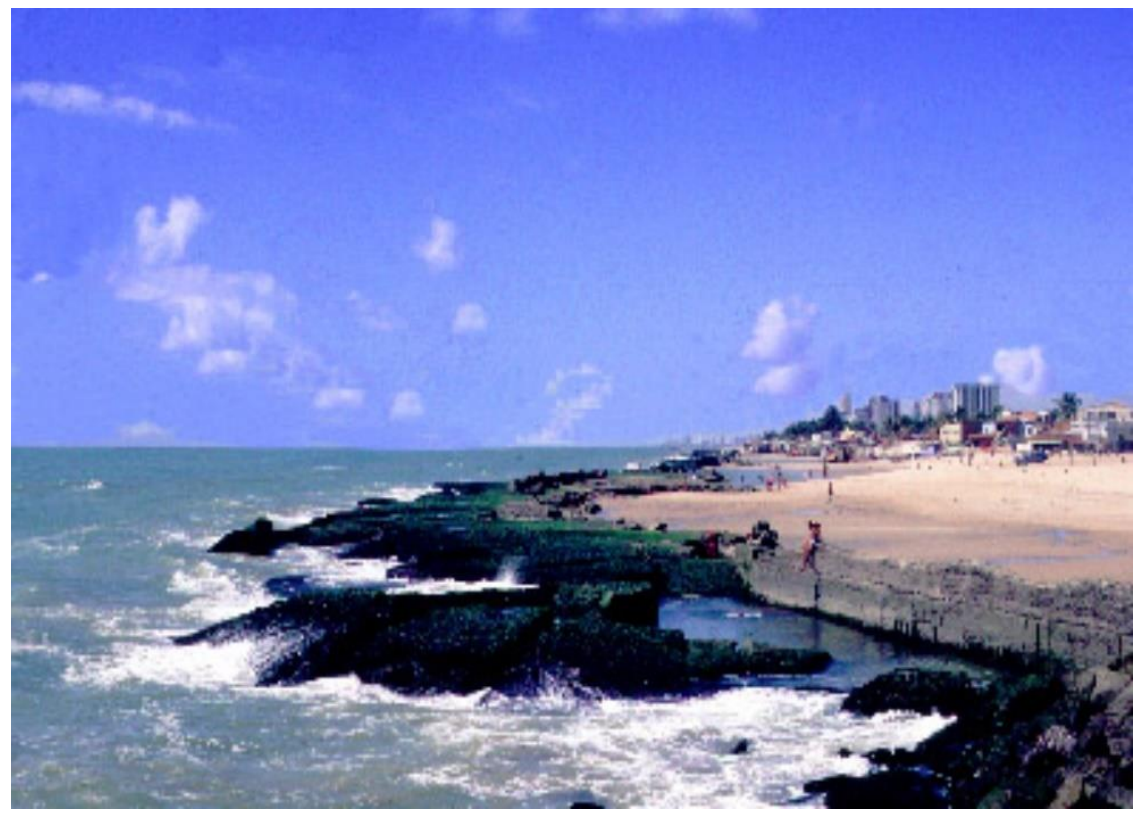

Figure 2 - Carpet algal identified at the site of collection

To describe the qualitative and quantitative variation of species of macroalgae from the
Praia do Pina, Recife-PE, in drought and rainy periods were collected in August 2007, 
corresponding to the rainy season and in January 2008 for the period of drought. The specimens of macroalgae were collected by snorkeling using the combined techniques of sampling belt transects $(50 \mathrm{~m} \times 1 \mathrm{~m})$ and quadrats $(1 \mathrm{~m} \times 1 \mathrm{~m})$. To follow this protocol a sample of 50 tape measure was attached to the reef, which at low tide was about 0.5 meters deep. For every meter of the measuring tape samples were collected and made photographic records of specimens that were within the area of 1 square meter ( $0.5 \mathrm{~m}$ to each side of the tape measure).

\section{RESULTS}

Table 1 presents data of the occurrence of macroalgae collected in the rainy season and drought. The representatives of the genus Halimeda, as described in work relating to the region studied macroalgae were not found in the two periods of study.

Through the distributed data in table 1 , it appears that the species Gracilaria Salicornia G.verrugosa and were not found in the rainy season, while Sargassum ilicifolium species was observed only during the rainy season (Figure 3). For the other species present, the frequency was similar to what occurred between the periods studied in the years 2007 and 2008, which shows little variation in abundance of macroalgae distibution and, for this time interval.

Table 1 - Species of macroalgae found in the Praia do Pina in the periods of study.

\begin{tabular}{|c|c|c|}
\hline Macroalgae found & Rainy Period & Period of drought \\
\hline Caulerpa filiformis & * & * \\
\hline C. lentillifera & * & * \\
\hline C.prolifera & * & * \\
\hline C.racemosa & * & * \\
\hline C.sertularioides & * & * \\
\hline Centroceras clavulatum & * & * \\
\hline Chaetomorpha antennina & * & * \\
\hline Chondracanthus acicularis & * & * \\
\hline Cladophora $s p$ & * & * \\
\hline Dictyota dichotoma & * & * \\
\hline Enteromopha flexuosa & * & * \\
\hline Gracilaria salicornia & - & * \\
\hline G.verrugosa & - & * \\
\hline Hypnea cervicornis & * & * \\
\hline H.musciformis & * & * \\
\hline H. pannosa & * & * \\
\hline Padina pavonica & * & * \\
\hline P. tetrastromatica & * & * \\
\hline Pterocladia capilacea & * & * \\
\hline
\end{tabular}


SILVA, E. V et al., AJMRR, 2019; 2:9

\begin{tabular}{|l|c|c|}
\hline Sargassum ilicifolium & $*$ & - \\
\hline S. Muticum & $*$ & $*$ \\
\hline S. vulgare & $*$ & $*$ \\
\hline Ulva fasciata & $*$ & $*$ \\
\hline U. intestinalis & $*$ & $*$ \\
\hline Ulva lactuca & $*$ & $*$ \\
\hline
\end{tabular}

\section{DISCUSSION}

In the area under study, the main causative agents of rainfall are the disturbances from the east (east of disturbances and waves) that occur from May to August characterizing the rainy season and other months are the period of drought. The temperature is high, with average between 22 and $26{ }^{\circ} \mathrm{C}$. The area has high insolation with total annual hours of bright sunshine of 2200 to 3200 . Evaporation is also high, ranging from 800 to $1800 \mathrm{~mm}$ annually. The annual average relative humidity ranges from $50 \%$ to $90 \%$. Dominate the trade winds with average speeds between 6.1 and 9.3 we welcome, especially from the east in the period October to March and south-southeast in the period April to September (ARAGÃO, 2004).

Among the various types of environments in the coastal zone, the environment of the beach is considered one of the shows great dynamism, with an important role in protection of the coast, due to the presence of ridges of sandstone, and is likely to be posted by anthropogenic impacts due to the large concentration of population and economic activities such as fishing, tourism, boating, recreation, among others (DOMINGUEZ, 1990).

According Villles and Spencer (1995) the coast pernambuco is subdivided by the Coastal Management Program of Pernambuco (GERCO - PE) in three sectors (Figure 3): North (Goiana, Itamaracá, Igarassu, Abreu e Lima, Paulista, Itapissuma and Itaquitinga ), Metropolitan (Olinda, Recife, Jaboatao dos Guararapes, São Lourenço da Mata, Camaragibe and Moreno) and South (Cabo de Santo Agostinho, Ipojuca, Sirinhaém, Rio Formoso, Tamandaré, Barreiros, São José da Coroa Grande).

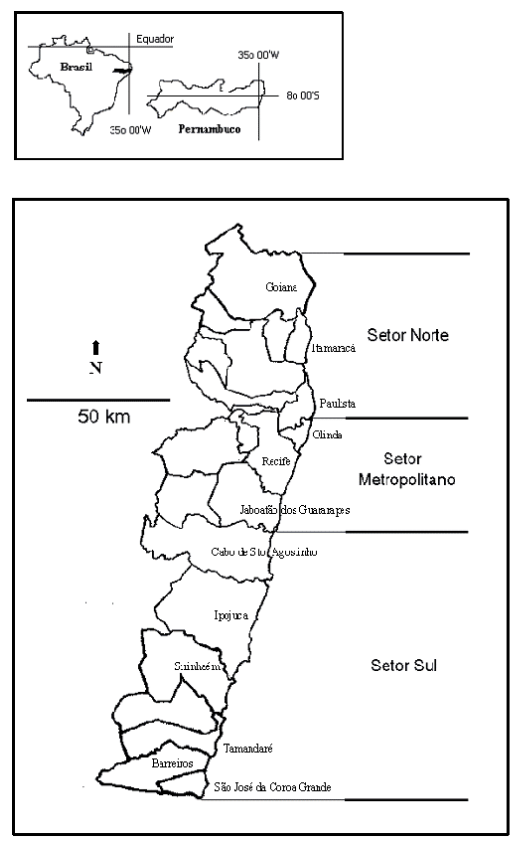

Figure 3 - Breakdown of Pernambuco in coastal areas. Source: GERCO - EP (www.cprh.pe.gov.br). 
In the coastline of the State of Pernambuco is serious environmental problem, with many stretches of coast in imbalance, showing marine erosion that gradually varies from moderate to severe (CPRH, 1998). This process is intensified by the urban occupation disorganized, with works that do not respect the limits of postbeach, which deforested and land areas of mangroves and coastal change the current.

The destruction of mangroves, which in coastal Pernambuco in recent twenty years, is in growth. The mangroves swamp serve as a filter and cleaning the area of contact between the range of terrestrial and marine ecosystems (PEREIRA et al., 2002).

The status of living at the beach, set up some decades ago, resulted not only in Pernambuco, but in most coastal areas, serious problems due mainly to modification of coastal hydrodynamic.

The increase of human populations who live, work and enjoy the resources of the area of the beach causes pressure that, along with others that are natural, should be monitored and understood for the preservation of the environment and for the maintenance of quality of life. Evidence of negative effects of human pressures are the loss of habitats such as areas between the tides, sandbanks, reefs of coral, the decline in water quality, algae blooms, declining commercial and artisanal fisheries, depletion of stocks of living resources, not -living, pollution, increase the processes of erosion and coastal flooding, etc.

Beside these factors addressed in anthropogenic negative notes that the state of Pernambuco has a number of power plants, factories and industries that contribute large amounts of contaminants from rivers that reach the beach (Rio Formoso, Jaboatao, Capibaribe, Beberibe and others). All these contribute to water quality in some areas becomes bad, influencing the soil, use for bath while affecting ecosystems in nearby areas.

We verified that the parts most affected by anthropogenic factors are located on the beaches of Guadalupe, Maracaípe, Porto de Galinhas, Suape, Barra de Jangada, Candeias, Piedade, Boa Viagem and every edge of the city of Olinda, Janga, Maria Farinha, Jaguaribe, Ponta de Pedras, Carne de Vaca, among others (PEREIRA, 2001).

The beaches of Brasilia Formosa, Pina, Boa Viagem and Piedade, located in the metropolitan area of Recife, were targets of major environmental impacts, such as coastal erosion, building expansion, pollution by discharges of domestic and industrial effluents.

Grenn (1968) related these trainers are factors of major pressures on the marine water, showing depletion in some areas, drastically affecting the instantaneous death of plankton, or to bioaccumulation.

This phenomenon is characterized by retention of toxic substances by living organisms which accumulate in your body and go to other beings in the food chain until you reach the man by poisoning, often fatal. In the midst of these pressures are of anthropogenic or natural origin, are disorders that are directly reflected in your community produces (primary and secondary), thus providing information on the degree of food availability within the ecosystem.

Pollution, certainly one of the factors most detrimental to the survival of algae has been observed in some parts of coastal Pernambuco, as occurs with the beach of Piedade, a beach of the Region Metropilitan. This urbanization, with installation of buildings and hotels in big without the proper infrastructure for sanitation, as occurs with the dumping of domestic sewage in the area intensified the process of eutrophication by promoting the growth of chlorophytes and Ulva fasciata (PEREIRA et al, 2002).

The species of the genus Caulerpa and Ulva are cited as bioindicators of pollution, accumulating about twice as nitrate and phosphate, purified water in these environments. Possibly, the toxicity of industrial organic compounds and may be associated with the occurrence of these species in the study area. 
The same was evident in our study, regarding the occurrence of these species, both during the rainy season and in the drought. The area of the collection Pina presents with the same features found on the beach of Piedade, which indicates that the level of pollution is high in Pina. Another aspect that deserves attention is a lack of work for restoration of water quality. The activities of craft fishing and other activities of informal work in the area contribute to strengthen the framework of pollution. Many products are marketed captured in the environment without supervision by the health monitoring and without basic structure.

Besides these human factors is also important to consider the dynamic processes of natural compounds by the actions of the agents of transport, erosion and deposition, among which, wind, rain and tide, also considering the variation in the level of the oceans.

\section{CONCLUSION}

The results obtained in this survey we can conclude that the species Ulva lactuca, Caulerpa sertularioides, Cladophora sp., Chondracanthus acicularis, Chaetomorpha antennina, Centroceras clavulatum, Hypnea musciformis, Ulva fasciata, U. intestinalis, Enteromopha flexuosa, which are presented in greater quantity in the study of coral reefs because they are indicator species of organic pollution, indicate that the Pina Beach is being subjected to an intensive process of eutrophication as a result of negative anthropogenic.

Only three species showed seasonal variation in occurrence during the period studied showed that the factor of eutrophication in the area may have masked the expression of other environmental factors on the distribution.

\section{ACKNOWLEDGMENTS}

The Brazilian Institute of Environment and Renewable Natural Resources (IBAMA). The Pro-Rector for Academic Affairs (PROACAD), Federal University of Pernambuco - UFPE.

\section{REFERENCES}

1. CASTRO, F. J. V. Variação temporal da meiofauna e da nematofauna em uma área mediterrânea da Bacia do Pina. Pernambuco, Brasil. 2003. 111p. Tese (Doutorado em Oceanografia) CTG. UFPE.

2. UNESCO. International Oceanographyc Table. Wormly: 1973. n.2, 14Ip.

3. TRAVASSOS, R E.R F. Hidrologia e biomassa primária do fitoplâncton do Estuário do rio Capibaribe, Recife - Pernambuco. Recife, 1991. 288p. Dissertação (Mestrado em Oceanografia Biológica) - Universidade Federal de Pernambuco, 1991.

4. TUNDISI, J. Produção primária "standing-stock" e fracionamento do fitoplâncton na região lagunar de Cananéia. São Paulo, 1969. I3Op. Tese (Doutorado) - Fac. Fil. Cien. Letr., Universidade de São Paulo, 1969.

5. SASSI, R., VELÔSO, T.M. G.; MELO, G. N.; MOURA, G. F. de. Variações diurnas do fitopiâncton e de parâmetros hidrológicos em Recifes costeiros do Nordeste do Brasil. in: ENCONTRO BRASILEIRO DE PLÂNCTON, 4., 1990, Recife. Anais Recife: UFPE, 1991. p. 61-82.

6. ARAGÃO, J. O. R. de. A influência dos oceanos Pacífico e Atlântico na dinâmica do tempo e do clima do Nordeste do Brasil. In Oceanografia Um cenário tropical: ESKINAZI-LEÇA, E.; NEUMANN-LE1TÃO, S.; COSTA, M. F. (Org.). Recife: Bagaço, 2004. p. 287-31 7.

7. SASSI, R. Fitoplâncton de formação recifal de Ponta do Seixas ([ai. $7^{\circ} 3^{\prime} 16^{\prime \prime}$ S - Long. $\left.34^{\circ} 47^{\prime} 35^{\prime \prime} \mathrm{W}\right)$, Estado da Paraíba, Brasil: composição ciclo anual e alguns aspectos físico-ecológicos. São Paulo, 1987. 163 p. Tese (Doutorado em Ciências - instituto Oceanográfico da Universidade de São Paulo, 1987.

8. SASSI, R., VELÔSO, T.M. G.; MELO, G. N.; MOURA, G. F. de. Variações diurnas do fitopiâncton e de parâmetros hidrológicos em Recifes costeiros do Nordeste do Brasil. in: ENCONTRO BRASILEIRO DE PLÂNCTON, 4., 1990, Recife. Anais. Recife: UFPE, 1991. p. 6182.

9. BOLD, H. C.; WYNNE, M. J. Introduction to the algae: structure and reproduction. Ed. Englewood Cliffs: Prentice-hail. 1985. 706p.

10. COUTINHO, P.N.; Lima, A.T.O.; Queiroz, C.M.; Freire, C.S.S.;A; et al. Estudo da erosão marinha nas praias de Piedade e Cadeias e no estuario de Barra de jangada Municipio de Jaboatão dos Guararapes-PE, Laboratório de Geologia e Geofisica Marinha-LGGM/UFPE, Relatorio Tecnico. 1997. 154p 
11. NUNES, J.M.C. Catálogo de algas marinhas bentônicas do estado da Bahia, Brasil. Acta Botân. Malacit, 1998. v. 23, p.5-21,

12. OLIVEIRA FILHO, A. Estudos preliminares de macroalgas como indicadoras das condições ambientais da área recifal nas praias de Boa Viagem e Pina, Pernambuco, Brasil. Monografia (Especialização) - Universidade Federal de Pernambuco. CTG. Departamento de Oceanografia, Gestão de Ambientes Costeiros Tropicais, 2001.

13. MARTINS, A.; ABU-RAYA, M.; FREITAS R. Distribuição das macroalgas marinhas na zona intertidal da ilha de São Vicente. Disponível em: http:/ /www.geocities.com/bmpc v /botani ca/grupo1.htm> 2000. Acesso em: 5 dez. 2001.

14. JOLY, A.B. Gêneros de algas marinhas da costa atlântica latino-americana. São Paulo: Editora da Universidade de São Paulo, 1967. 461 p.

15. COCENTINO, A.L.M. Família Rhodomelaceae (Ceramiales-Rhodophyta na praia de SerrambiPernambuco-Brasil). Dissertação de Mestrado Universidade Federal Rural de Pernambuco. Departamento de Botânica. 1994. 176p.

16. MARQUES JR., A.N.; MORAES, R.B.C.; MAURAT, M.C. Poluição marinha, In: Pereira, R.C.; Soares-Gomes, A. (org.), Biologia marinha. Editora Interciência. Rio de Janeiro, 2002, p. 311334.

17. PEREIRA, S.M.B.; OLIVEIRA-CARVALHO, M.F.; ACCIOLY, M.C.; ANGEIRAS, J.A.P. Macroalgas do Estado de Pernambuco/parte I - Chlorophyta. Livro de Resumos da VII Reunião Brasileira de Ficologia. Porto de Galinhas. 1999, p. 79,

18. PEREIRA, S. M. B., CARVALHO, M. F. O., ANGEIRAS, J. A. P., PEDROSA, M. E. B., OLIVEIRA, N. M. B., TORRES, J., GESTINAR, L. M. S., COCENTINO, A. L. M., SANTOS, . D., NASCIMENTO, P. R. F., CAVALCANTI, D. R. 2002. Algas marinhas bentônicas do Estado de Pernambuco. In TABARELLI, M., SILVA, J. M. C. (orgs) Diagnóstico da biodiversidade de Pernambuco. Editora Massangana, Recife, 5: 99124 (b).

19. SOUSA, G.S. Macroalgas como indicadoras da qualidade ambiental da Praia de Piedade-PE. Monografia (especialização) - Universidade Federal de Pernambuco. CTG. Departamento de Oceanografia. Gestão de Ambientes Costeiros Tropicais. 2001.

20. OLIVEIRA FILHO, E.C.; HORTA, P.A.; AMANCIO, C.E.; SANT'ANNA, C.L. Avaliação de áreas prioritárias para conservação da biodiversidade da zona costeira e marinha. Algas e angiospermas marinhas bênticas do litoral brasileiro. 1999. Disponível em: htpp://www.ib.usp./algamare-br> Acesso em: 28 de abril de 2008.

21. YONESHIGUE-BRAGA, Y. Flora marinha bentônicada Baía de Guanabara e cercanias. I. Chlorophyta. Instituto de Pesquisas da Marinha, Rio de Janeiro, Publicação, 1970a . v. 42, p.1-55.

22. YONESHIGUE-BRAGA, Y. Flora marinha bentônica da Baía de Guanabara e cercanias. II. - Phaeophyta. Instituto de Pesquisas da Marinha, Rio de Janeiro, Publicação, 1970b. v. 45, p.1-31.

23. YONESHIGUE, Y. Taxonomie et écologie des algues marines dans la région de Cabo Frio (Rio de Janeiro, Brésil). Doucteur de d'Etat-Sciences, Université d'Aix-Marseille, Marseille. 1985.

24. TEIXEIRA, V.L., PEREIRA, R.C., JÚNIOR, A.N.M., LEITÃO FILHO, C.M. \& SILVA, C.A.R. Seasonal variations in infralitoral seaweed communities under a pollution gradient in Baía de Guanabara. Rio de Janeiro: Ciência e Cultura. 1987. v. 39, p. 423-428.

25. PEREIRA, S.M.B.; RIBEIRO, F.A.; BANDEIRAPEDROSA, M.E. Algas pluricelulares do infralitoral da praia de Gaibu (PernambucoBrasil). Revista Brasileira de Biociências. 2007, v. 05 (02), p. 951-953.

26. ARAUJO, M.C.B.; SOUZA, S.T.; CHAGAS, A.C.O.; BARBOSA, S.C.T; COSTA, M.F. Análise da ocupação urbana das praias de Pernambuco, Brasil. Revista de Gestão Costeira Integrada, 2007, 7(2), 97-104.

27. VILLES, H.; SPENCER, T. Coastal Problems: Geomorphology, ecology and Society et the Coast. Edward Arnold, Map of Pernambuco State Coast, with the subdivision (North, Metropolitan and South setors), according to GERCO - PE (www.cprh.pe.gov.br).

28. DOMINGUEZ, J.M.L.; BITTENCOURT, A.C.S.P.; LEÃO, Z.M.A.N.; AZEVEDO, A.E.G. Geologia do quaternário costeiro do estado de Pernambuco. Revista Brasileira de Geociências, 1990, v. 20, p.208-215.

29. SANTOS, C.H.A; LOURENÇO, J.A. WIEGAND, M.C. PENAFORT, J.M. IGARASHI, M.A. Aspectos do cultivo de algas marinhas com vistas a sustentabilidade da atividade. Fortaleza: Universidade Federal do Ceará. Disponível em: http://www prex.ufc.br/formularios/Meio_Ambiente_2006. Acesso em: 15 mai. 2009.

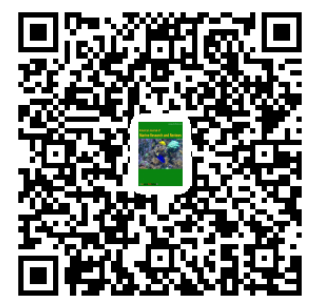


SILVA, E. V et al., AJMRR, 2019; 2:9

AJMRR: http://escipub.com/american-journal-of-marine-research-and-reviews/ 1 